\title{
Phylogenetically distant clade of Nostoc-like taxa with the description of Minunostoc gen. nov. and Minunostoc cylindricum sp. nov
}

\author{
Fangfang CAI ${ }^{1,2}$, Xiaochuang $\mathrm{LI}^{3}$, Ruozhen $\mathrm{GeNG}^{1,2}$, Xin PeNG ${ }^{1} \&$ Renhui $\mathrm{LI}^{1 *}$ \\ ${ }^{1}$ Key Laboratory of Algal Biology, State Key Laboratory of Freshwater Ecology and Biotechnology of China, \\ Institute of Hydrobiology, Chinese Academy of Sciences, Wuhan 430072, People's Republic of China; \\ *Corresponding author e-mail: reli@ihb.ac.cn, tel. (+86) 27 68780067, fax (+86) 2768780123 \\ ${ }^{2}$ University of Chinese Academy of Sciences, Beijing 100049, People's Republic of China \\ ${ }^{3}$ State Key Laboratory of Environmental Criteria and Risk Assessment, Chinese Research Academy of Environ \\ mental Sciences, Beijing 100012, PR China
}

\begin{abstract}
Two cyanobacterial strains morphologically identified to the genus Nostoc were isolated from a wet rocky wall in a mid-subtropical region in China, and they were taxonomically and phylogenetically characterized based on the polyphasic approach combining morphological and genetic characteristics. 16S rRNA gene sequence analysis showed that the two strains containing six clones were all $>99.6 \%$ similar to each other, but had $<94.3 \%$ similarities to the existing cyanobacterial genera. The phylogenies based on $16 \mathrm{~S}$ rRNA and rpoC1 gene sequences indicated that their sequences grouped into a unique and robust cluster with high bootstrap values. This unique cluster was separated from the clade of the 'Nostoc sensu stricto' and the respective clades formed by the morphologically similar genera Mojavia, Desmonostoc, Aliinostoc, Komarekiella and Halotia. The 16S-23S rRNA ITS secondary structure of the both strains exhibited the unique pattern of D1-D1', Box-B and V3 helix, distinguishing it from the other heterocytous genera. Such a clear cluster leads to the establishment of Minunostoc gen. nov., with the type species as Minunostoc cylindricum sp. nov.
\end{abstract}

Key words: Cyanobacteria, Minunostoc, New genus, Polyphasic approach, Taxonomy

\section{INTRODUCTION}

Cyanobacteria are one of the most important and the oldest primary producers capable of oxygenic photosynthesis, found in nearly all environments from polar to tropical areas (WhitTon \& PotTs 2000). Given the ubiquity of the distribution and the enormous importance of cyanobacteria in the biosphere, creation of a clear and comprehensible taxonomic system of cyanobacteria is highly needed. Cyanobacteria have been traditionally classified using morphological criteria, however this approach showed to be potentially problematic owing to high phenotypic plasticity occurring in the same species or at different growth stages under culture (CASAMATTA et al. 2003; DvořÁK et al. 2012; HAŠLER et al. 2012; SHALYGIN et al. 2017). The systematics and taxonomy of cyanobacteria have been undergoing substantial changes by employing molecular markers, most notable as the 16S rRNA gene and Internal Transcribed Spacer (ITS) regions (JOHANSEN \& CASAMATTA 2005; HAŠLER et al. 2012; DVořÁK et al. 2014; HAšLER et al. 2014). As a result, some filamentous cyanobacterial groups are found to be polyphyletic and sometimes intermixed with unicellular forms (LYRA et al. 2001; HofFMANN et al. 2005; RAJANIEMI et al. 2005a), strongly implying the need for taxonomic revision. Therefore, phylogenetic analyses based on DNA sequences have become the basis for restructuring cyanobacterial systematics at different catagories, and led to the establishment of new groups, such as new families including Tolypothrichaceae and Godleyaceae (HAUER et al. 2014), Aphanizomenonaceae (KomÁReK et al. 2014), Dapisostemonaceae (HeNTSCHKE et al. 2016), Oculatellaceae and Trichocoleaceae (MAI et al. 2018). Furthermore, a variety of novel cyanobacterial genera, particularly heterocytous groups, were proposed, such as the Dolichospermum (WACKLIN et al. 2009), Sphaerospermopsis (ZAPOMĚLová et al. 2009), Chrysosporum (ZAPOMĚLová et al. 2012), Cyanocohniella (KAŠTOvsKÝ et al. 2014), Roholtiella (BoHUNICKA et al. 2015) and Dactylothamnos (KomÁReK et al. 2015). Although great improvements have been made in the modern classification of cyanobacteria, there still exist some groups whose taxonomic revisions are needed. The Nostocaceae is among one of the most morphologically complex cyanobacteria, and this family includes unbranched heterocytous cyanobacteria with the ability to 
produce akinetes. Several genera, Anabaena, Trichormus and Wollea, are arguably polyphyletic, and partial taxonomic revision in these genera involved combination and separation among some taxa (RAJANIEMI et al. 2005a; KozHevniKov \& KozHevniKova 2011, Kust et al. 2015; Kust et al. 2018). Nostoc, the type genus of this family, is probably the most problematic one since it contains complicated and widely distributed cyanobacterial types. Phylogenetic results have shown that Nostoc is polyphyletic (RAJANIEMI et al. 2005a, b). Recently, several novel genera, Mojavia (Řeháková et al. 2007), Desmonostoc (HrouzeK et al. 2013), Halotia (GENuÁrio et al. 2015), Komarekiella (HENTSCHKE et al. 2017), Aliinostoc (BAGCHI et al. 2017) and Compactonostoc (CAI et al. 2018), which morphologically appears to be Nostoc-like, have been proposed and separated from the 'Nostoc sensu stricto' clade based on the phylogenetic analysis of the $16 \mathrm{~S}$ rRNA gene sequences. Over 300 species of the genus Nostoc have been described and many of which are not identifiable according to modern taxonomic system and need further investigation and revision. It is expected that more new taxa will be proposed from this polyphyletic genus in the near future (KOMÁREK et al. 2014).

The purpose of this study is to present two novel strains of cyanobacteria isolated from soil habitat from a mid-subtropical region, China. These two novel strains were morphologically similar to Nostoc, however, molecular analyses on the 16S rRNA gene, 16-23S internal transcribed spacer (ITS) region and $r p o \mathrm{C} 1$ gene revealed these two strains to form a separate clade from Nostoc. Accordingly, we described here a new genus of filamentous cyanobacteria, Minunostoc.

\section{Material ANd Methods}

Sampling and cultivation. Samples were collected in October 2014 from the Small Seven-hole Scenic Area (2515'34.79"N, $\left.107^{\circ} 42^{\prime} 46.72 " E\right)$, Guizhou province, China. Visible growths of cyanobacteria on a wet rocky wall were collected with the ladle. Using the micropipette washing method to isolate the heterocytous filaments into unialgal cultures, two strains of Nostoc-like cyanobacteria were obtained and cultured in screw-capped tubes containing BG11 medium. The strains were kept at $25^{\circ} \mathrm{C}$ under a $12 \mathrm{~h}: 12 \mathrm{~h} \mathrm{LD}$ cycle with a photon flux density of $30 \mu \mathrm{mol} \cdot \mathrm{m}^{-2} . \mathrm{s}^{-1}$ from white fluorescent lamps. The formation of heterocysts in the strains was evaluated in cultured filaments exposed to the BG110 medium (N-free BG11 medium). The strains were maintained in the Harmful Algae Biology Herbarium (CHAB) of the Institute of Hydrobiology, China, and coded as CHAB 5843 and CHAB 5844-1 respectively.

Morphological characterization. Morphological observation was carried out using a Nikon Eclipse 80i microscope (Nikon, Japan). Trichome size was measured from $\geq 50$ individuals using a Nikon eclipse $80 \mathrm{i}$ light microscope with DS-Ri1 digital camera (Nikon, Japan). The image was analyzed using the NIS-Elements D 3.2.

DNA extraction and PCR amplification. Unialgal cultures were harvested and the total genomic DNA was extracted using the modified cetyltrimethylammonium bromide (CTAB) method adopted by NeILAN et al. (1995). The primers PA and B23S (EDwARDs et al. 1989; GKeLIS et al. 2005) were used for amplification of 16S rRNA gene, the primers 322 and 340 (ITEMAN et al. 2000) were used to obtain 16S-23S internal transcribed spacer (ITS), and primers rpoC1-F (5'GATTGGGAATGYCATTGYGGYAA-3') and rpoC1-R (5'-CATCGGCTTTTCGTTCCCCACAA-3') were used for amplification of $r p o \mathrm{C} 1$ gene. $\mathrm{PCR}$ was performed in an MJ Mini Personal Thermal Cycler (Bio-Rad, Hercules, California USA), and the amplification program was carried out as follows: one cycle of $3 \mathrm{~min}$ at $94{ }^{\circ} \mathrm{C} ; 30$ cycles of $30 \mathrm{~s}$ at $94{ }^{\circ} \mathrm{C}, 30 \mathrm{~s}$ at 58 ${ }^{\circ} \mathrm{C}\left(30 \mathrm{~s}\right.$ at $55^{\circ} \mathrm{C}$ for ITS and rpoC1), and $1 \mathrm{~min}$ at $72{ }^{\circ} \mathrm{C}(30 \mathrm{~s}$ for ITS and 20s for rpoC1) and then a final 5 min elongation step at $72{ }^{\circ} \mathrm{C}$. The PCR amplification products were purified by QIAquik PCR purification columns (Qiagen, Germany) according to manufacturer's manual and then cloned into the pMDTM18-T vector (TaKaRa, TaKaRa BioInc., Otsu, Japan). The cloning procedure employed by SAMBrooK \& RuSSELL (2001) was performed. Sequencing was carried out using an ABI 3730 Automated Sequencer (PerkinElmer, Waltham, Massachusetts USA).

Phylogenetic analysis. 16S rRNA and rpoC1 gene sequences obtained from Nostoc and those related sequences of cyanobacterial strains cited from GenBank were used for phylogenetic analyses. All the sequences were aligned using CLUSTAL X version 2.0 (LARKIN et al. 2007). The final phylogenetic trees were constructed using neighbor-joining (NJ), maximum likelihood (ML), and Bayesian inference (BI). The $\mathrm{NJ}$ analysis using Kimura-2 model upon default parameters with 1000 bootstrap replicates was run via MEGA software v7.0 (KUMAR et al. 2016), the ML algorithms were performed using PAUP V4.0b10 (SWOFFORD 2003) and Bayesian inference were analyzed with MrBayes 3.2.2 (RonQuist et al. 2012). The ModelTest 3.06 PosADA and CRANDALL, 1998) program was used to explore the sequence evolution model that fitted the dataset based on Akaike information criterion (AIC). The best-fit models, selected for the ML and BI analyses of the 16S rRNA gene and $r p o \mathrm{C} 1$ gene were $\mathrm{GTR}+\mathrm{I}+\mathrm{G}$, the obtained consensus phylogenetic tree was edited with Tree View 1.6.6 (PAGE 1996). Chroococcidiopsis thermalis PCC7203 and Oscillatoria tenuis CCAP 1459/4 were chosen as the outgroup taxon for two genes respectively. The obtained nucleotide sequences have been deposited in the GenBank database with accession numbers MH918062-MH918063, MK045294-MK045297, MH919979-MH919980 and MH992098-MH992099.

16S-23S rRNA ITS secondary structures of D1-D1', Box-B and V3 helices were determined using RNA structure, version 5.6 (MATHEWS LAB 2013).

\section{RESULTS}

\section{Minunostoc F. Cai et R. Li gen. nov.}

Description: Colonies macroscopic, irregularly clustering, gelatinous, free-living on wet rocky wall, blue-green. Filaments flexuous, freely entangled, sheath usually present, colourless. Vegetative cells barrel-shaped, and more or less longer than wide. Heterocytes and akinetes not known. 
Type species: Minunostoc cylindricum F. Cai et R. Li Etymology: The name of genus 'Minunostoc' was chosen due to the small cylindrical cells.

Minunostoc cylindricum F. Cai et R. Li sp. nov. (Fig. 1) Description: Colonies are macroscopic, gelatinous, irregularly clustered, free-living on wet rocky wall in the form of irregular, amorphous, blue-green gelatinous clusters. Filaments flexuous, freely entangled. Sheath usually present, colourless. Vegetative cells barrel-shaped, 3.1-(4.3)-5.4 $\mu \mathrm{m}$ long, 2.5- (3.2)-3.8 $\mu \mathrm{m}$ wide, length: width ratio 1.3 . Heterocytes and akinetes were not observed during 3 years of observation. In the BG11 and BG110 medium, the novel strains were never shown to form heterocysts. The strains did not grow in the BG110 medium, since the cultures started to bleach after 4 days of incubation in this medium.

Holotype here designated: Harmful Algae Biology Herbarium (CHAB) of the Institute of Hydrobiology, Wuhan, China. CHAB5843 and CHAB5844-1.

Reference strains: CHAB 5843, CHAB 5844-1.

Type locality: Small Seven-hole Scenic Area, Guizhou province, China $\left(25^{\circ} 15^{\prime} 34.79^{\prime \prime} \mathrm{N}, 107^{\circ} 42^{\prime} 46.72^{\prime \prime} \mathrm{E}\right)$.

Habitat: Free-living on wet rocky wall.

Etymology: cylindricum, refereeing to the cylindrical cells of the strain.

\section{Molecular and phylogeny analysis}

The evolutionary distance based on the 16S rRNA gene showed that two Minunostoc strains containing six clones shared 99.6-99.9\% similarity with each other (Table 1 ), but all six clones had $<94.3 \%$ similarities with the closet genera (Nostoc 93.5\%-94.1\%, Desmonostoc 94.1\%-94.2\%, Komarekiella 94.2\%-94.3\%, Halotia 92.5\%-92.6\%, Compactonostoc 93.8\%-93.9\%, and Aliinostoc $92.5 \%-92.6 \%$ ).

Based on 16S rRNA gene sequences from 97 cyanobacterial taxa including CHAB5843 and CHAB5844-1 in this study, the phylogenetic trees were constructed using the NJ, ML, and Bayesian methods. The ML tree showed that the two strains were grouped into a unique clade (Fig. 2), and this unique cluster was further supported by NJ, ML, BI approaches with high bootstrap values of $100 \%, 100 \%$, and 1.00 respectively. Consistent with the $16 \mathrm{~S}$ rRNA gene phylogeny, the rpoC1 phylogeny showed that the both strains formed a distinctive lineage, clearly in the outside of the Nostoc clade (Fig. 3).

\section{ITS secondary structures}

The ITS regions containing both tRNAs, from our obtained strains in this study, together with the sequences derived from GeneBank, were used to construct the ITS secondary structure. In total, three Nostoc species, two Desmonostoc species, one Halotia, Mojavia, Komarekiella, Goleter, Trichormus, Aliinostoc, Compactonostoc species and Minunostoc (CHAB5843, 5844-1) were used to infer their relationship within Nostocaceae.
Analyses on the secondary structures of D1-D1' helix (Fig. 4) revealed similar arrangements in several genera. Compared with other taxa, Minunostoc CHAB5843 and CHAB5844-1 possessed a unique structure. All other taxa exhibited smaller terminal loops (3-6 bp, Fig. 4A-4M), whereas Minunostoc had a pronounced, terminal loop (12 bp, Fig. 4N). Moreover, Minunostoc had two unidirectional bulges at the base of the stem, contrast to other taxa without this structure.

Shown in Fig. 5, the Box-B helix of Minunostoc consisted of $4 \mathrm{bp}$ (GGAA) helix in the base of the stem, followed by a 5:3 base bilateral bulge, and then further followed by a 1:2 base bilateral bulge, and the terminal loop contained $3 \mathrm{bp}$ bases (Fig. $5 \mathrm{~N}$ ), which was different from other taxa.

Although basal portion of V3 helix was conserved in sequences, the V3 of Minunostoc was also quite distinct from the V3 helix in all other taxa (Fig. 6). In details, the V3 helix of Minunostoc consisted of very long stems (10 bp), followed by a 1:2 base bilateral bulge, and further followed by a 5 bp terminal loop (Fig. $6 \mathrm{~N}$ ).

\section{Discussion}

It is well known that morphological features alone do not reflect their evolutionary and phylogenetic relationships in cyanobacteria. After introducing molecular data into cyanobacterial classification, many cyanobacteria from different categories are proven as polyphyletic (Wilmotte \& Golubić 1991; Wilmotte \& Herdman 2001; GugGer et al. 2002a, b; HofFMAnN et al. 2005; RAJANIEMI et al. 2005a, b; KomÁREK et al. 2014). It is expected that genera and species in modern taxonomic system of cyanobacteria will be ideally monophyletic (KomÁReK et al. 2014). At genus level, KomáreK et al. (2014) emphasized that it is better to have narrowly defined, monophyletic genera with relatively few species than large, poorly defined polyphyletic genera with many unrelated species. During this continuous revisionary process, many studies were concentrating on some large polyphyletic genera to build the small and unambiguously defined genera using the polyphasic characterization-based approach.

The genus Nostoc is a well known case as a complex genus. It is difficult to clearly differentiate related taxa within the genus based solely on morphology owing to the huge amount of heterogeneity (SINGH ET AL. 2016), and many previous studies using the polyphasic approach led to the establishment of new genera by splitting from Nostoc. In this study, establishing the new genus Minunostoc is a case along the taxonomic revision on Nostoc-like cyanobacterial taxa. New genetic and ecological results supported the description of this novel genus. The phylogenetic analysis based on $16 \mathrm{~S}$ rRNA gene sequences of several nostocacean genera resulted in the formation of 14 clusters (Fig. 2). Among the Nostoc morphotype clusters, clades B, C, D, E, F, G 


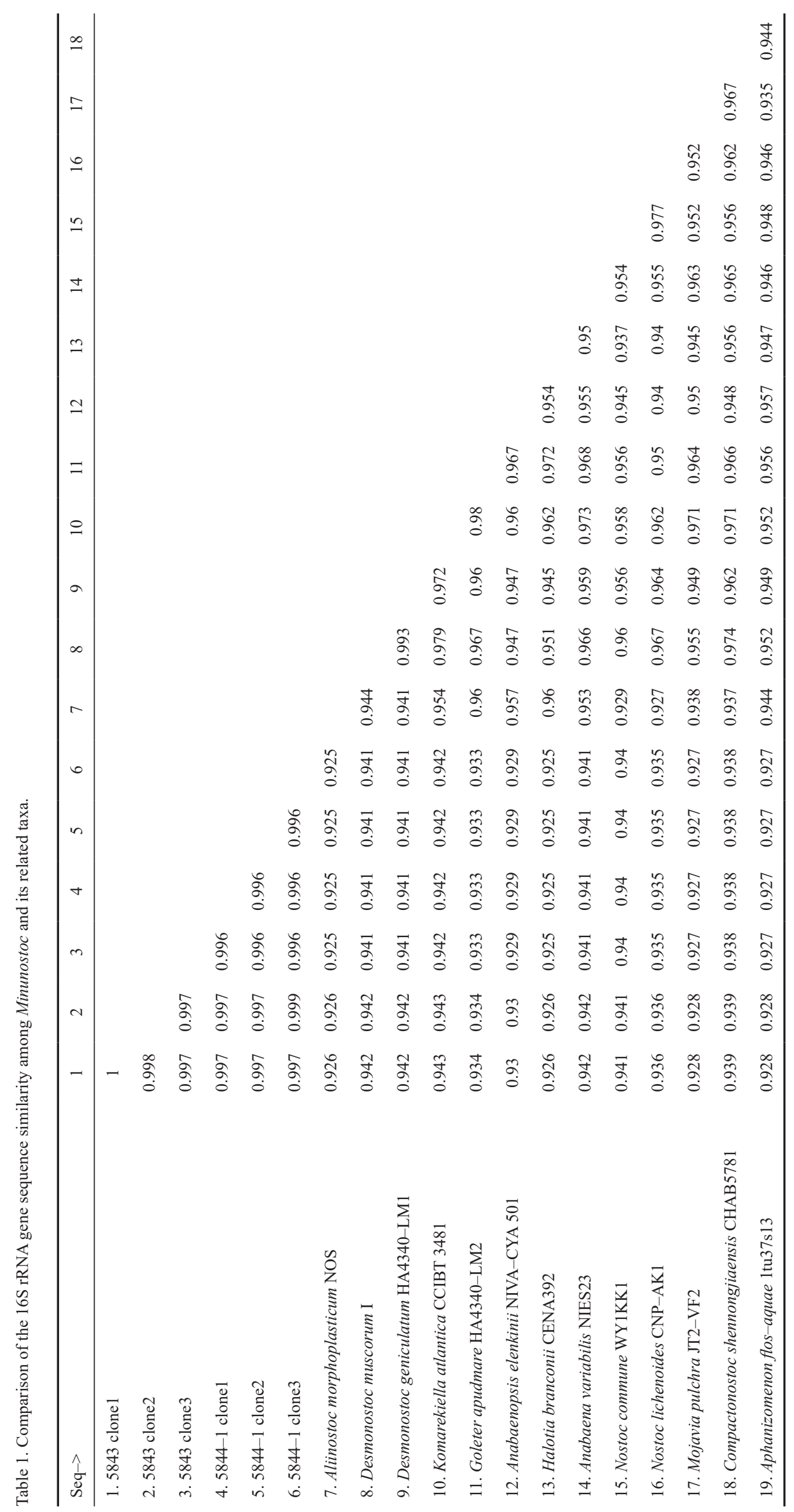



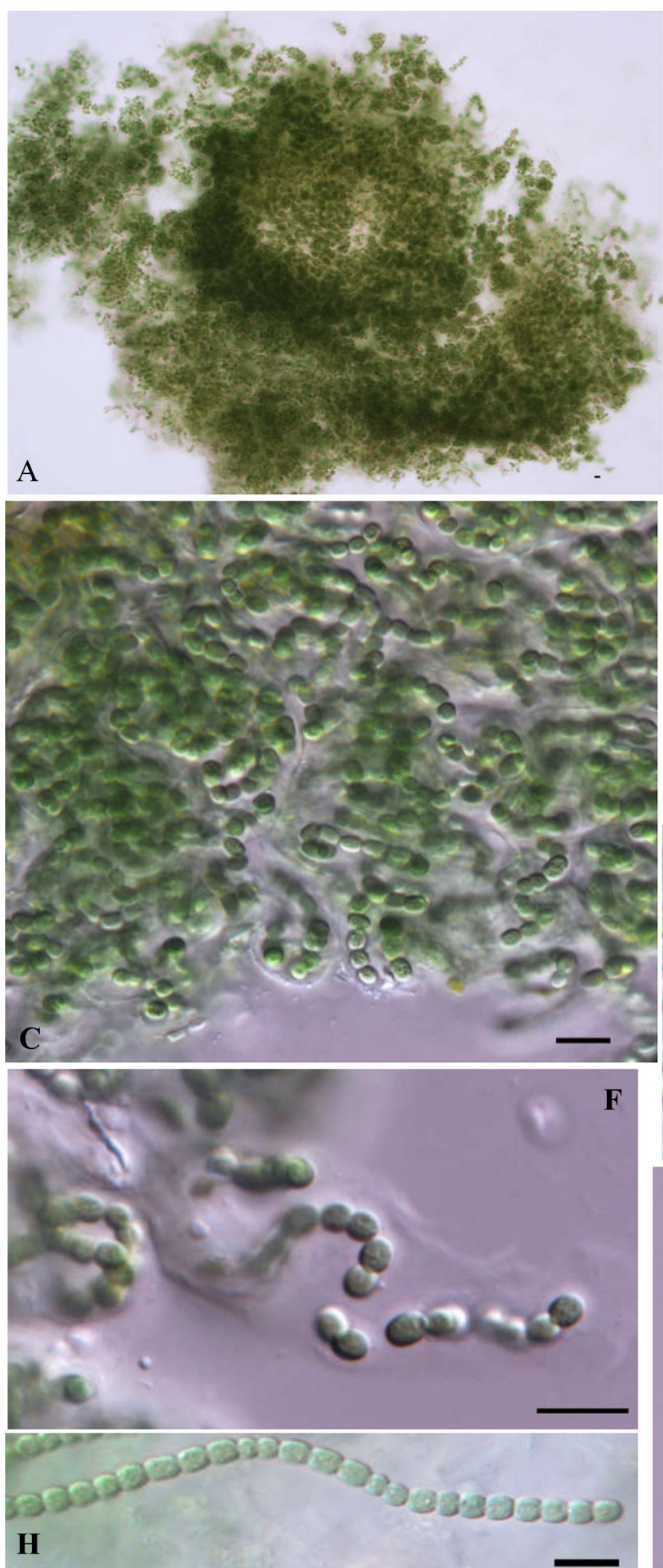

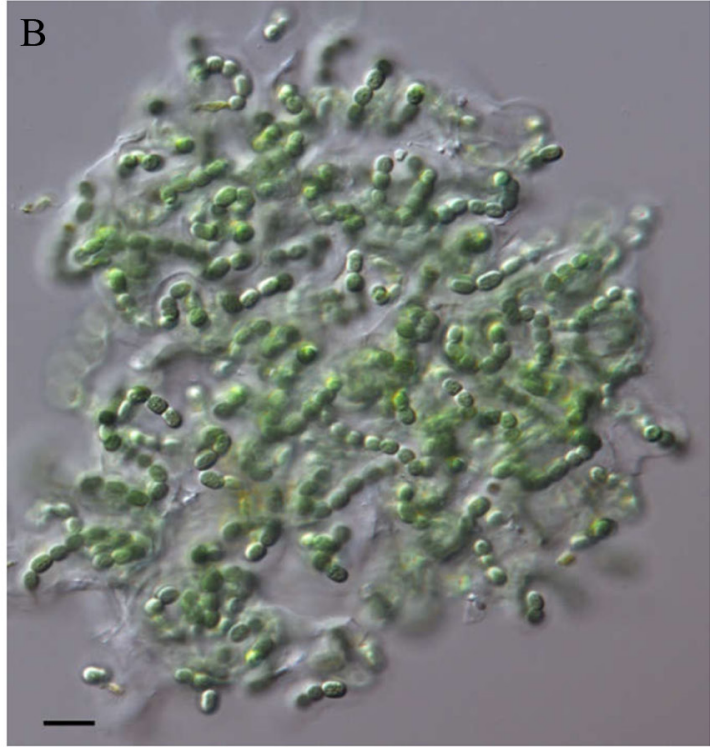

D
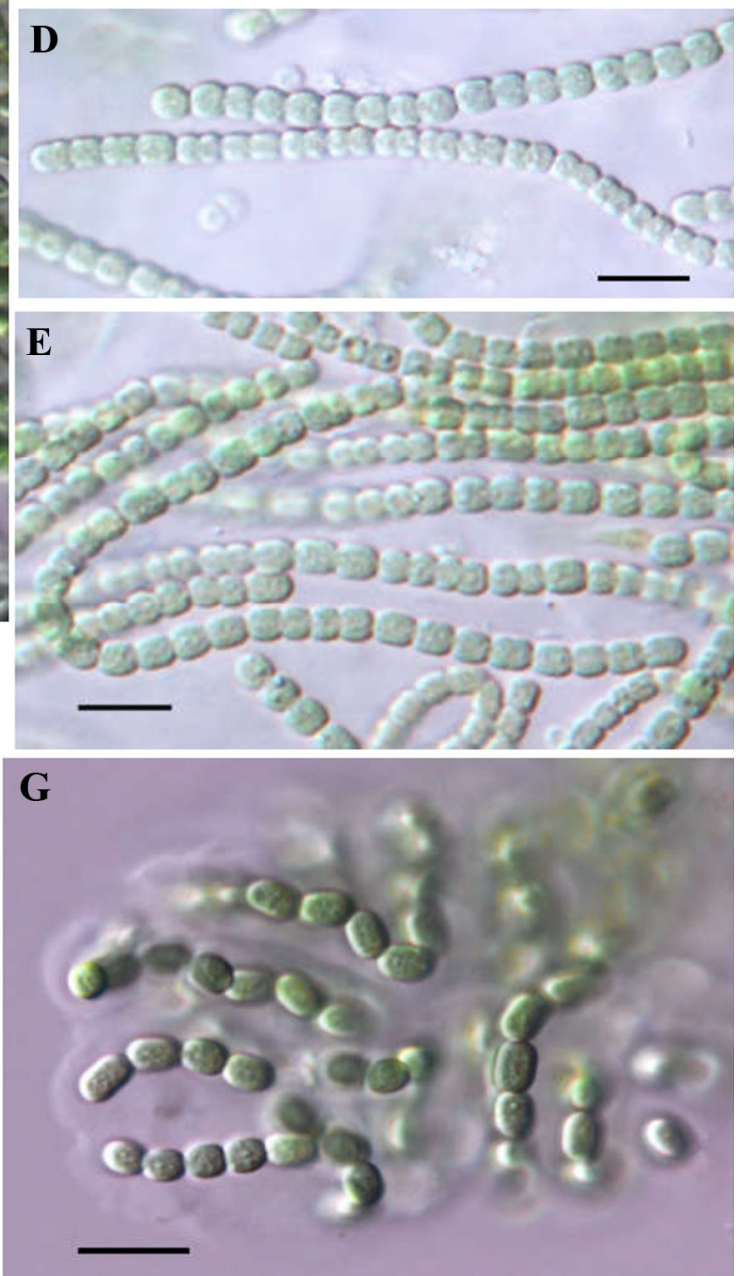

Fig. 1. Micrographs of Minunostoc cylindricum under the light microscopy (LM). (A) general view of microcolonies; (B, C, G) colonies wrapped by diffluent mucilaginous sheath; (D, E, H) single trichomes; (F) single trichomes with sheath. Scale bars $10 \mu \mathrm{m}$. 


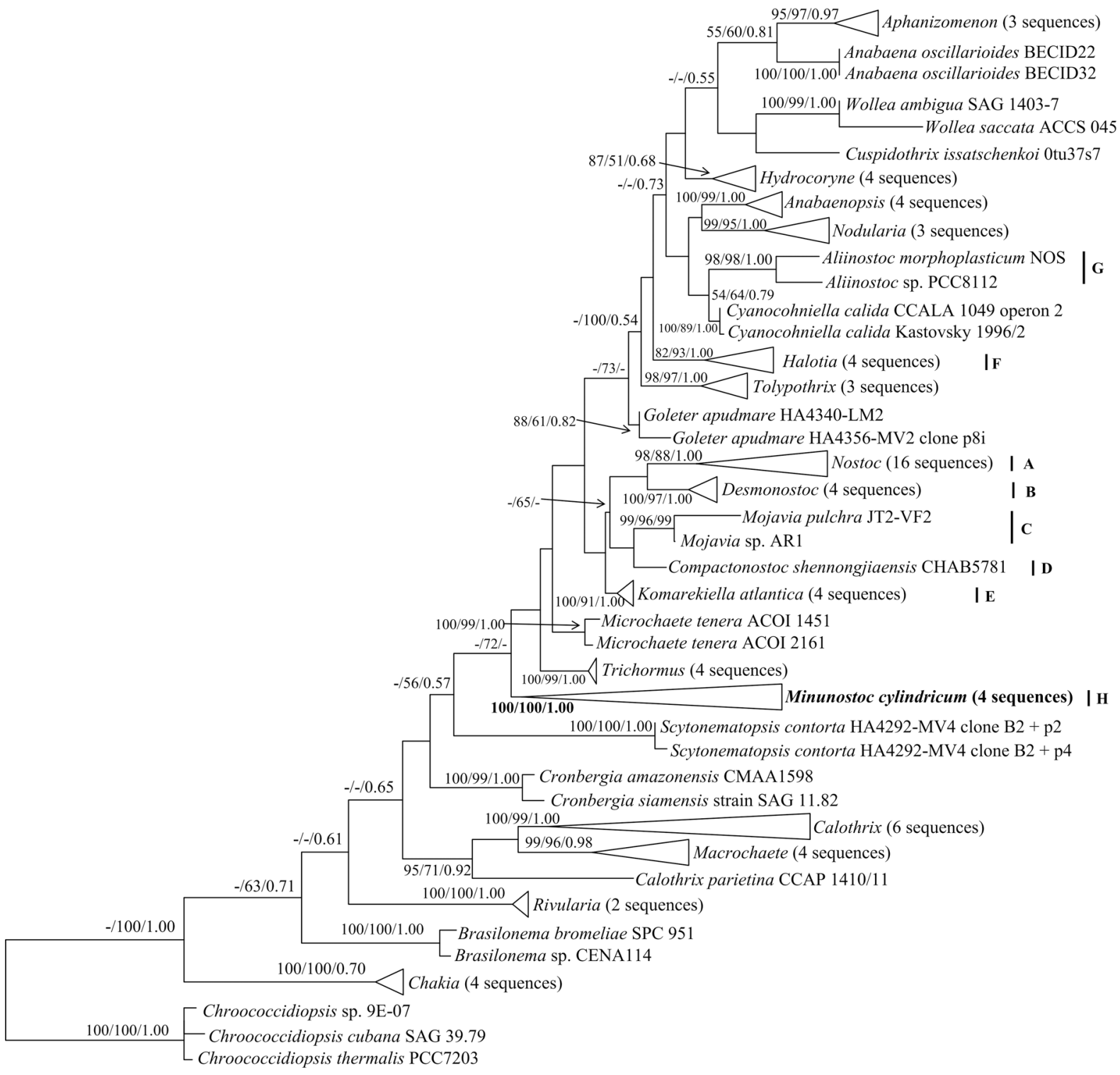

0.09

Fig. 2. Maximum likelihood (ML) phylogenetic tree based on 16S rDNA sequences (1068bp) of Minunostoc cylindricum and other cyanobacterial strains. Bootstrap values greater than $50 \%$ with NJ/ML/Mrbayes methods are indicated on the tree. The novel species is in bold font.

and $\mathrm{H}$ were phylogenetically divided. Cluster F consisted of sequences from the recently described genus Halotia, with its type species Halotia branconii isolated from biofilms in Antarctica and having tolerance of $1-10 \%$ $\mathrm{NaCl}$. Cluster $\mathrm{C}$ consisted of two sequences from the genus Mojavia. Cluster $\mathrm{G}$ also contained sequences from the recently described genus Aliinostoc, which morphologically appears to be Nostoc-like, but phylogenetically separated from Nostoc sensu stricto. Cluster E contained the newly established genus Komarekiella. The core Nostoc cluster including the type species Nostoc commune was placed in cluster A, supported by bootstrap values of $98 \%, 88 \%$ and 1.00 (NJ, ML and Bayesian analyses). The sequences from the strains of the novel genus Minunostoc were placed in a unique cluster $\mathrm{H}$, outside of the core Nostoc clade by NJ, ML and
Bayesian analyses. 16S rRNA gene sequence similarities between Minunostoc and the closet genera were shown as less than $94.3 \%$, below the bacterial genus cut-off in which a similarity limit of $95 \%$ was recommended as being intergeneric (WAYNE et al. 1987; STACKEBRANDT \& Goebel 1994; Stackebrandt \& Ebers 2006). The rpoC1 sequence-based phylogeny was the same as that from the 16S rRNA gene sequences since Minunostoc strains were grouped into a single clade separating from the Nostoc groups.

The secondary folding patterns of the $16 \mathrm{~S}-23 \mathrm{~S}$ ITS were also very different from those of the closely related taxa within the Nostocaceae. D1-D1', Box-B and V3 helix of Minunostoc were quite unique in comparison with those of Nostoc, Desmonostoc, Mojavia, Halotia, Komarekiella, Aliinostoc and Compactonostoc, 


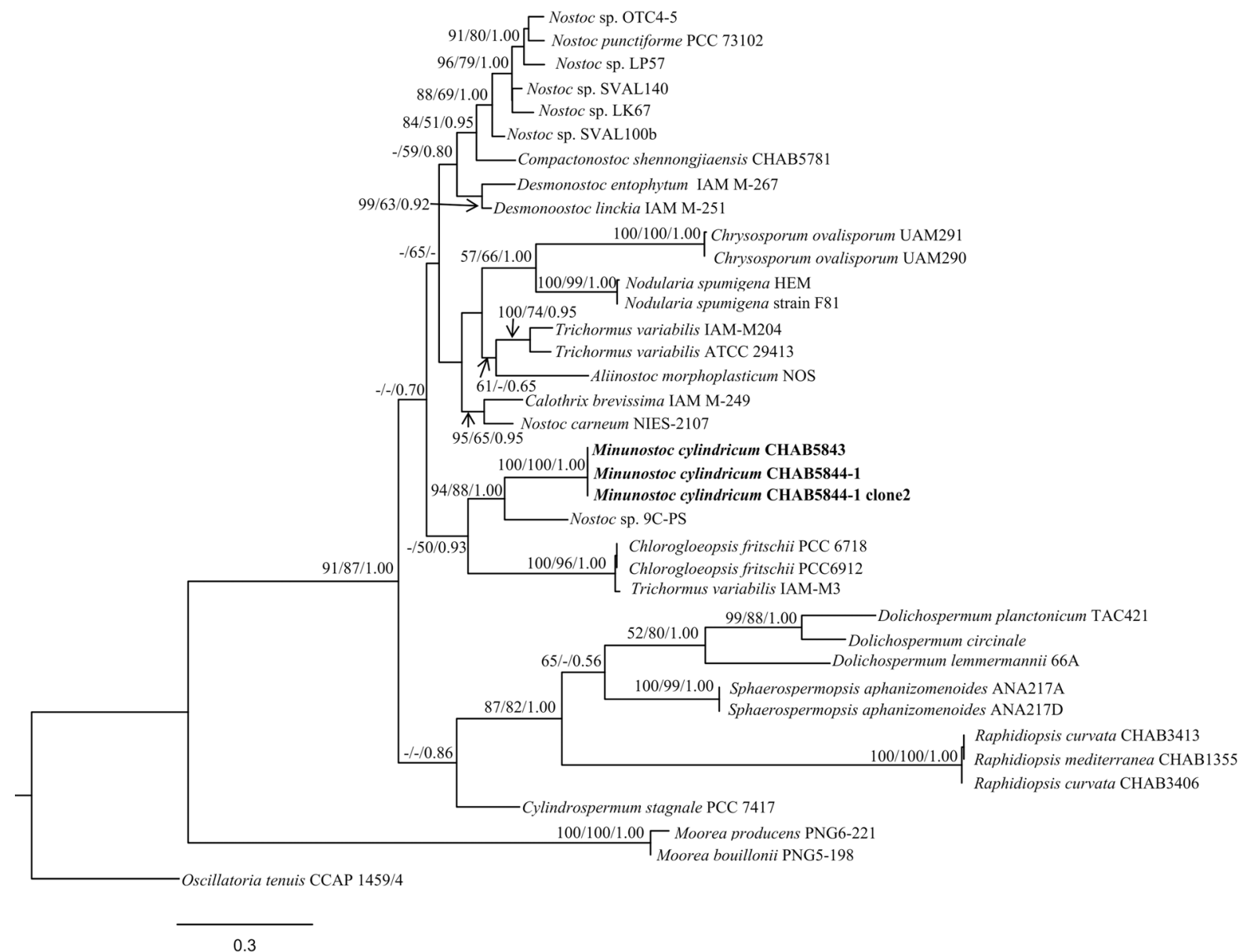

Fig. 3. Maximum likelihood (ML) phylogenetic tree of $r p o \mathrm{C} 1$ gene sequences. Bootstrap values greater than $50 \%$ with NJ/ML/Mrbayes methods are indicated on the tree. The novel species is in bold font.

supporting the establishment of this new genus.

The genus Minunostoc will become the seventh genus separating from Nostoc after introduction of the polyphasic approach. However, the unique morphological features in the genus Minunostoc included absence of heterocytes and akintes, and no small spherical colonies formation along the whole life cycle. By the detailed morphological comparison among Minunostoc and those genera recently separating from Nostoc including Mojavia, Desmonostc, Halotia, Komarekiella, Aliinostoc and Compactonostoc, Minunostoc differs from Mojavia, Halotia, Komarekiella and Compactonostoc since it does not form the aggregated filaments of microcolonies. Komarekiella have the typical type of germination of akinetes, originating a bigger vegetative cell and a smaller heterocyte as its first division. Both Desmonostoc and Minunostoc possess the same type of cell division in trichomes with colonies wrapped by diffluent mucilaginous sheath, however long chains of akinetes (10 or more cells) typically occurring in Desmonostoc were never observed in Minunostoc in the whole life cycle. Aliinostoc has only slight amount of sheath usually present in the apical portions of the filaments, quite distinct from Minunostoc with the filaments embedded in diffluent mucilaginous envelope in the most of the life cycle.
In conclusion, a few but unique morphological features shown in the filamentous cyanobacterial strains examined in this study, plus the strong molecular evidences based on 16S rRNA gene sequence homology, the phylogenetic relationship, and 16S-23S ITS secondary structures, it is strongly recognized that the novel genus of Minunostoc represents a new monophyletic group in the cyanobacterial systematics.

\section{ACKNOWLEDGMENTS}

The present study was supported by the grant from National Natural Science Foundation of China (NSFC 31470310). The research was supported by the Wuhan Branch, Supercomputing Center, Chinese Academy of Sciences, China

\section{REFERENCE}

BaGchi, S.N.; Dubey, N. \& Singh, P. (2017): Phylogenetically distant clade of Nostoc-like taxa with the description of Aliinostoc gen. nov. and Aliinostoc morphoplasticum sp. nov. - International Journal of Systematic and Evolutionary Microbiology 67: 3329-3338.

Bohunicka, M.; Pietrasiak, N.; Johansen, J.R.; Berrendero Gomez, E.; Hauer, T.; Gaysina, L. \& Lukesova, A. 

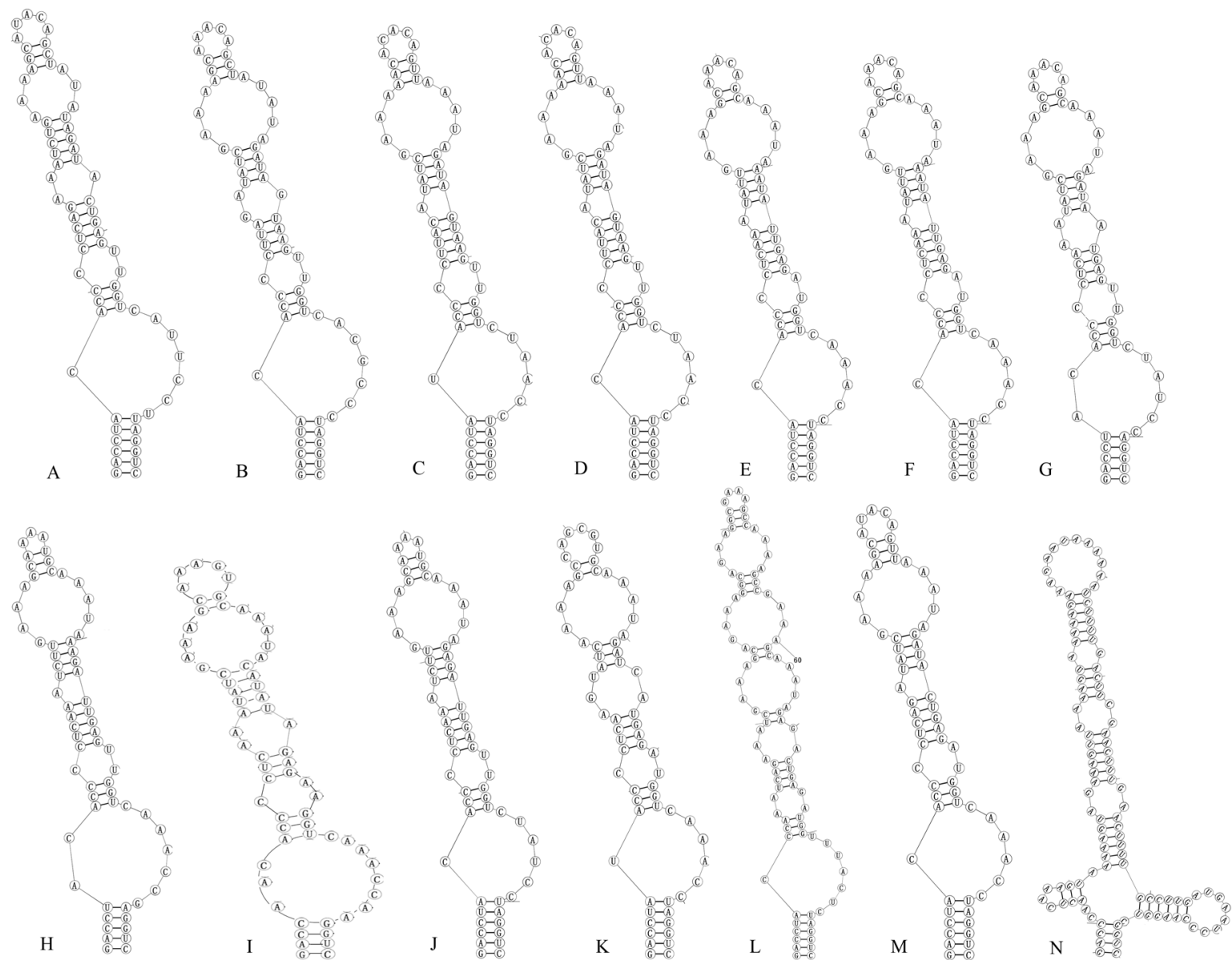

Fig. 4. D1-D1' helix in Minunostoc cylindricum and other heterocytous cyanobacteria: (A) Nostoc commune WY1-KK1; (B) Nostoc lichenoides CNP-AK1; (C) Nostoc punctiforme PCC73102; (D) Nostoc desertorum CM1-VF14; (E) Desmonostoc geniculatum HA4340-LM1; (F) Desmonostoc muscorum CENA18-D1; (G) Mojavia pulchra JT2-VF2; (H) Halotia branconii CENA392; (I) Komarekiella atlantica CCIBT 3481; (J) Goleter apudmare HA4340-LM2; (K) Trichormus anomalus HA4352-LM2; (L) Aliinostoc morphoplasticum NOS; (M) Compactonostoc shennongjiaensis CHAB5781; (N) Minunostoc cylindricum CHAB5843, CHAB5844-1.

(2015): Roholtiella, gen. nov. (Nostocales, Cyanobacteria) - a tapering and branching cyanobacteria of the family Nostocaceae. - Phytotaxa 197: 84-103.

CAI, F.; LI, X.; YANG, Y.; JiA, N.; HuO, D.; LI, R. (2018): Compactonostoc shennongjiaensis gen. et sp. nov. (Nostocales, Cyanobacteria) from a wet rocky wall in China. - Phycologia (in press)

Casamatta, D.A.; Vis, M.L. \& Sheath, R.G. (2003): Cryptic species in cyanobacterial systematics: a case study of Phormidium retzii (Oscillatoriales) using 16S rDNA and RAPD analyses. - Aquatic Botany 77: 295-309.

DvoŘÁk, P.; HAŠLER, P. \& PoulíčKovÁ, A. (2012): Phylogeography of the Microcoleus vaginatus (cyanobacteria) from three continents - a spatial and temporal characterization. - PLOS ONE 7: e40153.

Dvořák, P.; Hindák, F.; Hašler, P.; Hindáková, A. \& PoulíčKovÁ, A. (2014): Morphological and molecular studies of Neosynechococcus sphagnicola, gen. et sp. nov. (Cyanobacteria, Chroococcales). - Phytotaxa 170: 24-34.

DvořÁK, P.; JAHODÁŘová, P.H.; Gusev, E. \& PoulíčKovÁ, A. (2015): A new tropical cyanobacterium Pinocchia polymorpha gen. et sp. nov. derived from the genus Pseudanabaena. - Fottea 15:113-20.

Edwards, U.; Rogall, T.; Blocker, H.; Emde, M. \& Bottger,
E.C. (1989): Isolation and direct complete nucleotide determination of entire genes. Characterization of a gene coding for $16 \mathrm{~S}$ ribosomal RNA. - Nucleic Acids Research 17: 7843-7853.

GenuÁrio, D.B.; VAZ, M.G.M.V.; HentschKe, G.S.; SANT'AnNA, C.L.; \& Fiore, M.F. (2015): Halotia gen. nov., a phylogenetically and physiologically coherent cyanobacterial genus isolated from marine coastal environments. International journal of systematic and evolutionary microbiology 65: 663-675.

Gkelis, S.; Rajaniemi, P.; Vardaka, E.; Moustaka-Gouni, M.; LANARAS, T. \& Sivonen, K. (2005): Limnothrix redekei (Van Goor) Meffert (Cyanobacteria) strains from Lake Kastoria, Greece form a separate phylogenetic group. - Microbial Ecology 49: 176-182.

Gugger, M.; Lyra, C.; Henriksen, P.; Coute, A.; Humbert, J.F. \& Sivonen, K. (2002a): Phylogenetic comparison of the cyanobacterial genera Anabaena and Aphanizomenon. - International Journal of Systematic and Evolutionary Microbiology 52: 1867-1880.

GugGer, M.; Lyra, C.; SuOminen, I.; TsitKo, I.; Humbert, J.F.; Salkinoja-Salonen, M.S. \& Sivonen, K. (2002b): Cellular fatty acids as chemotaxonomic markers of the genera Anabaena, Aphanizomenon, Microcystis, Nostoc and Planktothrix (cyanobacteria). - International 

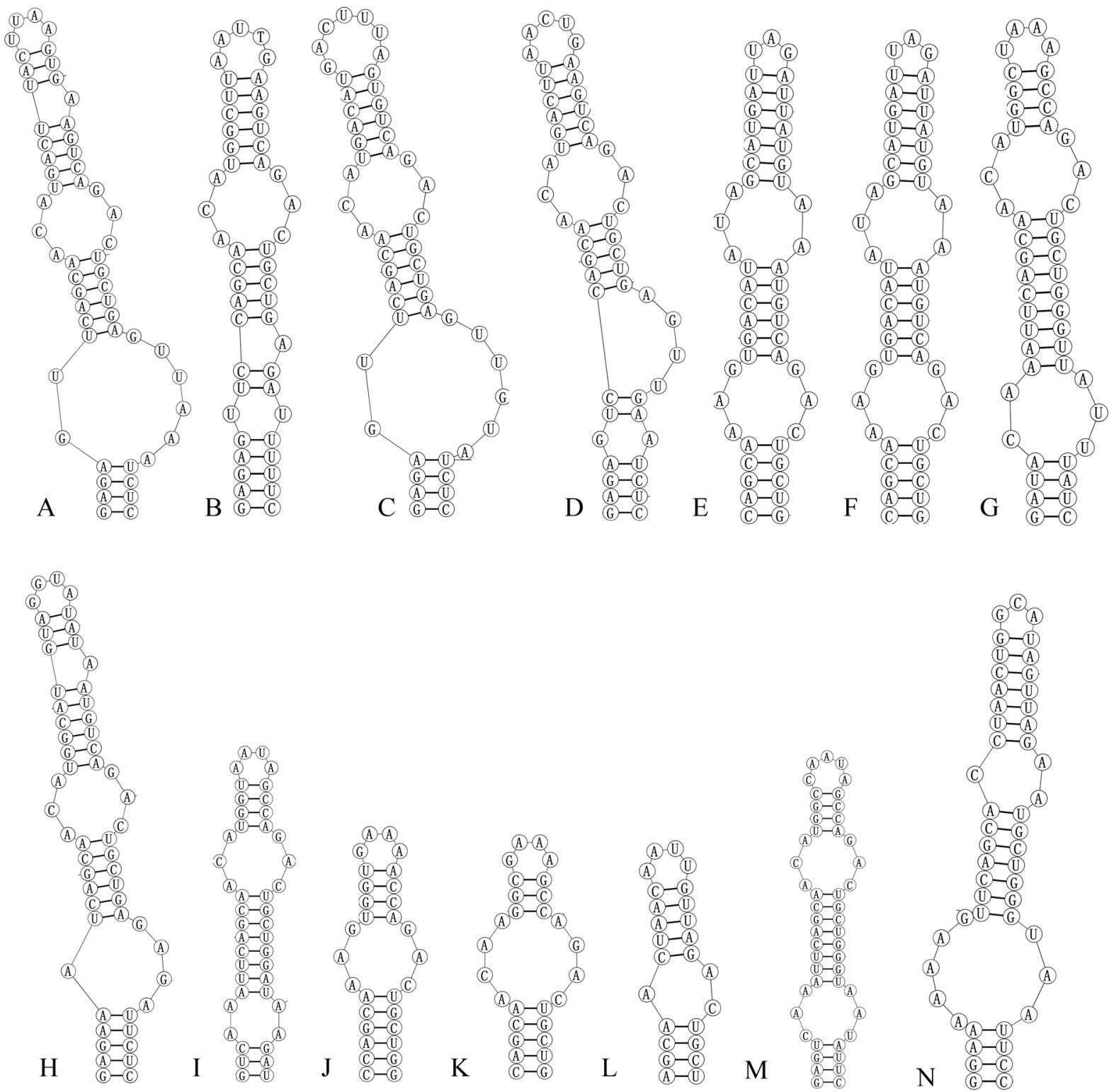

Fig. 5. Box-B helix in Minunostoc cylindricum and other heterocytous cyanobacteria: (A) Nostoc commune WY1-KK1; (B) Nostoc lichenoides CNP-AK1; (C) Nostoc punctiforme PCC73102; (D) Nostoc desertorum CM1-VF14; (E) Desmonostoc geniculatum HA4340-LM1; (F) Desmonostoc muscorum CENA18-D1; (G) Mojavia pulchra JT2-VF2; (H) Halotia branconii CENA392; (I) Komarekiella atlantica CCIBT 3481; (J) Goleter apudmare HA4340-LM2; (K) Trichormus anomalus HA4352-LM2; (L) Aliinostoc morphoplasticum NOS; (M) Compactonostoc shennongjiaensis CHAB5781; (N) Minunostoc cylindricum CHAB5843, CHAB5844-1.

Journal of Systematic and Evolutionary Microbiology 52: 1007-1015.

HaŠLER, P.; DVOŘÁK, P.; JohanSEn, J.R.; KitNeR. M.; ONDŘEJ, V. \& PoulíčKovÁ, A. (2012): Morphological and molecular study of epipelic flamentous genera Phormidium, Microcoleus and Geitlerinema (Oscillatoriales, Cyanophyta/Cyanobacteria). - Fottea 12: 341-356.

HAŠLER, P.; DvoŘÁK, P. \& PoulíčKová, P. (2014): A new genus of flamentous epipelic cyanobacteria, Johansenia. Preslia 86: 81-94.

Hašler, P.; DvoŘák, P.; Poulíč́ová, A. \& Casamatta, D.A. (2014): A novel genus Ammassolinea gen. nov. (Cyanobacteria) isolated from sub-tropical epipelic habitats. - Fottea 14: 241-248.

Hauer, T.; Mares, J.; Bohunicka, M.; Johansen, J.R. \&
BERRENDERO-GoMEZ, E. (2014): Heterogeneity of the cyanobacterial genus Microchaete: reassessment of the family Microchaetaceae and establishment of new families Tolypothrichaceae and Godleyaceae. - J. Phycol. 50: 1089-100.

Hentschke, G.S.; Johansen, J.R.; Pietrasiak, N.; Rigonato, J.; Fiore, M.F. \& SANT'ANNA, C.L. (2017): Komarekiella atlantica gen. et sp. nov. (Nostocaceae, Cyanobacteria): a new subaerial taxon from the Atlantic Rainforest and Kauai, Hawaii. - Fottea 17: 178-190.

HoffMann, L.; KomÁreK, J. \& KĂStovskÝ, J. (2005): System of cyanoprokaryotes (Cyanobacteria) - state in 2004. - Algological Studies 117: 95-115.

HrouzeK, P.; Lukešová, A.; Mareš, J. \& Ventura, S. (2013): Description of the cyanobacterial genus Desmonostoc 

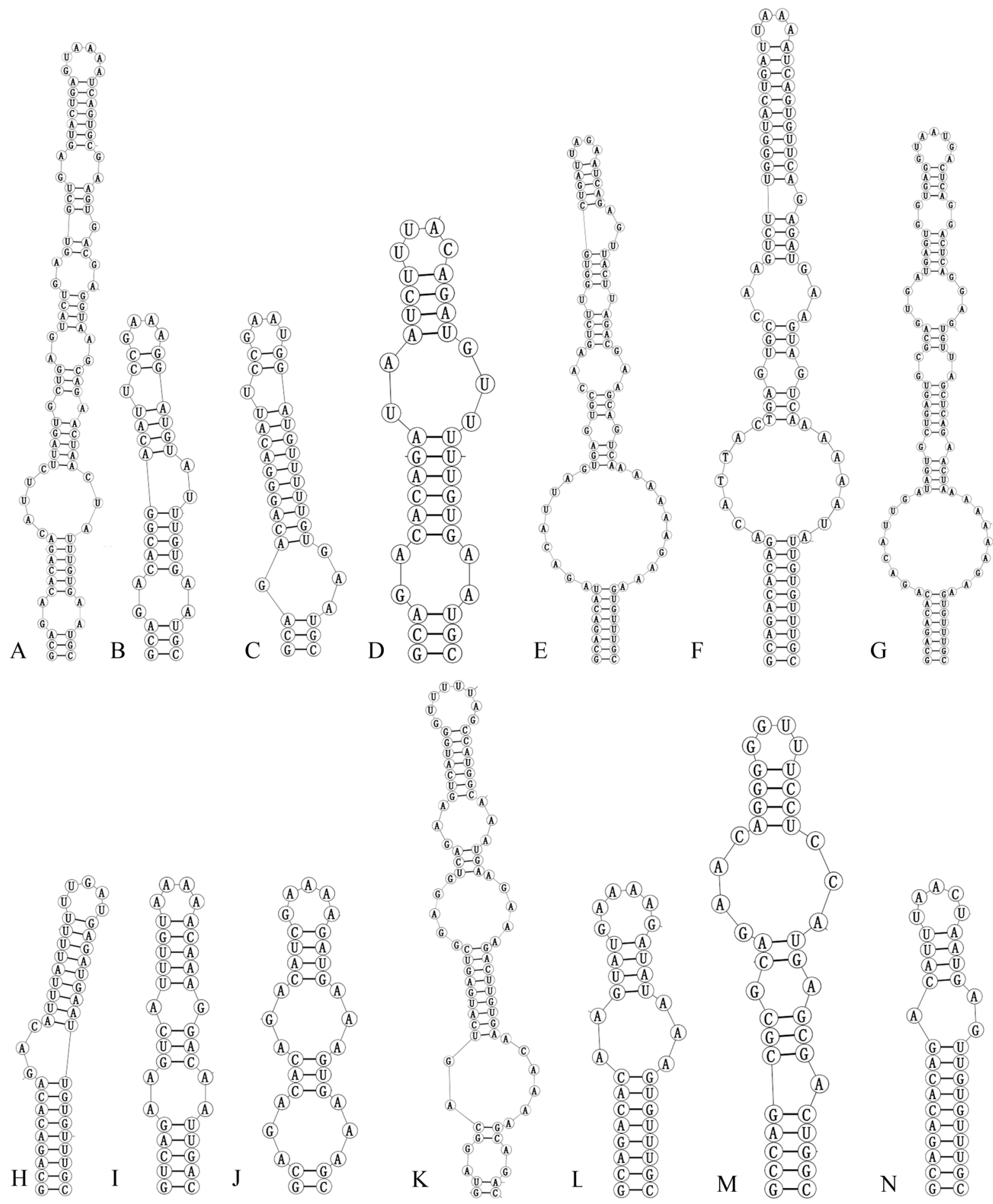

Fig. 6. V3 helix in Minunostoc cylindricum and other heterocytous cyanobacteria: (A) Nostoc lichenoides CNP-AK1; (B) Nostoc commune WY1-KK1; (C) Nostoc punctiforme PCC73102; (D) Nostoc desertorum CM1-VF14; (E) Desmonostoc geniculatum HA4340-LM1; (F) Desmonostoc muscorum CENA18-D1; (G) Mojavia pulchra JT2-VF2; (H) Halotia branconii CENA392; (I) Komarekiella atlantica CCIBT 3481; (J) Goleter apudmare HA4340-LM2; (K) Trichormus anomalus HA4352-LM2; (L) Aliinostoc morphoplasticum NOS; (M) Compactonostoc shennongjiaensis CHAB5781; (N) Minunostoc cylindricum CHAB5843, CHAB5844-1.

gen. nov. including D. muscorum comb. nov. as a distinct, phylogenetically coherent taxon related to the genus Nostoc. - Fottea 13: 201-213.

HentschKe, G.S.; Johansen, J.R.; PietrasiaK, N., et al. (2016): Phylogenetic placement of Dapisostemon gen. nov. and Streptostemon, two tropical heterocytous genera
(Cyanobacteria)[J]. - Phytotaxa 245: 129-143.

Iteman, I.; Rippka, R.; TANDeAu, De Marsac, N. \& Herdman, M. (2000): Comparison of conserved structural and regulatory domains within divergent $16 \mathrm{~S}$ rRNA-23S spacer sequences of cyanobacteria. - Microbiology 146: $1275-1286$. 
Johansen, J.R. \& Casamatta, D.A. (2005): Recognizing cyanobacterial diversity through adoption of a new species paradigm. - Algological Studies 117: 71-93.

KaštovskÝ, J.; Berrendero Gomez, E.; HLADIL, J. \& JohanSEN, J.R. (2014): Cyanocohniella calida gen. nov. et spec. nov. (Cyanobacteria: Aphanizomenonaceae) a new cyanobacterium from the thermal springs from Karlovy Vary, Czech Republic. - Phytotaxa 181: 279-92.

KomáreK, J.; Kaštovský, J.; Mareš, J. \& Johansen, J.R. (2014): Taxonomic classification of cyanoprokaryotes (cyanobacterial genera) 2014 according to the polyphasic approach. - Preslia 86: 295-335.

KomáreK, J.; GenUARIO, D.B.; Fiore, M.F. \& Elster, J. (2015): Heterocytous cyanobacteria of the Ulu Peninsula, James Ross Island, Antarctica. - Polar Biol. 38: 475-92.

KomÁREK, J. (2008): The cyanobacterial genus Macrospermum [J]. - Fottea 8: 79-86.

Kozhevnikov, I.V. \& KozHevnikova, N.A. (2011): Phylogenetic and morphological evaluation of Wollea saccata (Nostocales, Cyanobacteria) isolated from the Yenissei River basin. - Fottea 11: 99-106.

Kumar, S.; Stecher, G. \& Tamura, K. (2016): MEGA7: Molecular Evolutionary Genetics Analysis version 7.0 for bigger datasets. - Molecular Biology and Evolution 33: $1870-1874$.

Kust, A.; KoZlíKovÁ-ZapomĚLovÁ, E.; Mareš, J. \& Řeháková, K. (2015): A detailed morphological, phylogenetic and ecophysiological analysis of four benthic Anabaena (Nostocales, Cyanobacteria) strains confirms deep hetero-geneity within the genus. - Fottea 15: 191-202.

Kust, A.; Urajová, P.; HrouzeK, P.; Čapková, K.; Štenclová, L.; Řeháková, K. \& Mareš, J. (2018): A new microcystin producing Nostoc strain discovered in broad toxicological screening of non-planktic Nostocaceae (cyanobacteria). - Toxicon 150: 66-73.

Larkin, M.A.; Blackshields, G.; Brown, N.P.; Chenna, R.; Mcgettigan, P.A.; Mcwilliam, H.; Valentin, F.; Wallace, I.M.; Wilm, A.; LoPEZ, R.; ThOMPSON, J.D.; Gibson, T.J. \& Higgins, D.G. (2007): Clustal W and Clustal X version 2.0. - Bioinformatics 23: 2947-2948.

Lyra, C.; Suomalainen, S.; Gugger, M.; Vezie, C.; Sundman, P.; Paulin, L. \& Sivonen, K. (2001): Molecular characterization of planktic cyanobacteria of Anabaena, Aphanizomenon, Microcystis and Planktothrix genera. - International Journal of Systematic and Evolutionary Microbiology 51: 513-526.

Mai, T.; Johansen, J. R.; Pietrasiak, N.; Bohunicka, M. \& Martin, M. P. (2001): Revision of the Synechococcales (Cyanobacteria) through recognition of four families including Oculatellaceae fam. nov. and Trichocoleaceae fam. nov. and six new genera containing 14 species. Phytotaxa 365: 1-59.

Mathews LAB. (2013): RNAstructure version 5.6. http://rna. urmc. rochester.edu/RNAstructure.html.

Nelissen, B.; Wilmotte, A.; Neefs, J.M. \& De Wachter, R. (1994): Phylogenetic relationships among filamentous helical cyanobacteria investigated on the basis of $16 \mathrm{~S}$ ribosomal RNA gene sequence analysis. - Systematic and Applied Microbiology 17: 206-210.

NüBel, U.; Garcia-Pichel, F. \& Muyzer, G. (2000): The halotolerance and phylogeny of cyanobacteria with tightly coiled trichomes (Spirulina Turpin) and the description of Halospirulina tapeticola gen. nov., sp. nov. - International journal of systematic and evolutionary microbiology 50: 1265-1277.
Orcutt, K.M.; Rasmussen, U.; WebB, E.A.; Waterbury, J.B.; Gundersen, K. \& Bergman, B. (2002): Characterization of Trichodesmium spp. by genetic techniques. - Applied and environmental microbiology 68: 2236-2245.

Page, R.D.M. (1996): TreeView: An application to display phylogenetic trees on personal computers. - Computer Applications in the Biosciences 12: 357-358.

Posada, D. \& Crandall, K.A. (1998): Modeltest: testing the model of DNA substitution. - Bioinformatics 14: 817-818.

Rajaniemi, P.; Hrouzek, P.; Kaštovská, K.; Willame, R.; Rantala, A.; Hoffmann, L.; KomáReK, J. \& Sivonen, K. (2005a): Phylogenetic and morphological evaluation of the genera Anabaena. Aphanizomenon, Trichormus and Nostoc (Nostocales, Cyanobacteria). - Int. J. Syst. Evol. Microbiol. 55: 11-26.

Rajaniemi, P.; Komárek, J.; Hrouzek, P.; Willame, R.; KaštovsKÁ, K.; HoffmanN, L. \& Sivonen, K. (2005b): Taxonomic consequences from the combined molecular and phenotype evaluation of selected Anabaena and Aphanizomenon strains. - Algological Studies 117: 371-391.

Ronquist, F.; Teslenko, M.; Van Der Mark, P.; Ayres, D.L.; Darling, A.; Hohna, S.; Larget, B.; Liu, L.; Suchard, M.A. \& HuelsenbeCK, J.P. (2012): MrBayes 3.2: Efficient Bayesian Phylogenetic Inference and Model Choice Across a Large Model Space. - Systematic Biology 61: 539-42.

Řeháková, K.; Johansen, J.R.; Casamatta, D.A.; Xuesong, L. \& VinCENT, J. (2007): Morphological and molecular characterization of selected desert soil cyanobacteria: three species new to science including Mojavia pulchra gen. et sp. nov. - Phycologia 46: 481-502.

SAmbrook, J. \& Russell, D.W. (2001): Molecular cloning: a laboratory manual. -2344 pp., CSHL Press, Cold Spring Harbor, New York.

Shalygin, S.; Shalygina, R.; Johansen, J. R.; Pietrasiak, N.; Berrendero, E.; Bohunická, M. \& Sheil, C.A. (2017): Cyanomargarita gen. nov. (Nostocales, Cyanobacteria): convergent evolution resulting in a cryptic genus. - Journal of Phycology 53: 762-777.

Singh, P.; Shaikh, Z.M.; Gaysina, L.A.; Suradkar, A. \& Samanta, U. (2016): New species of Nostoc (cyanobacteria) isolated from Pune, India, using morphological, ecological and molecular attributes. - Plant Syst Evol. 302: 1381-1394.

StaCKebrand, E. \& Goebel, B.M. (1994): Taxonomic note: a placefor DNA-DNA reassociation and 16S rRNA sequence analysisin the present species definition in bacteriology. - International Journal of Systematic Bacteriology 44: 846-849.

Stackebrandt, E. \& Ebers, J. (2006): Taxonomic parameters revisited: tarnished gold standards. - Microbiol. Today 33: 152-155.

Suda, S.; Watanabe, M.M.; Otsuka, S.; Mahakahant, A.; YongmanitCHAI, W.; NopartNARAPORN, N. \& DAY, J.G. (2002): Taxonomic revision of water-bloom-forming species of oscillatorioid cyanobacteria. - International Journal of Systematic and Evolutionary Microbiology 52: $1577-1595$.

SwOFFord, D.L. (2003): PAUP*: Phylogenetic analysis using parsimony (*and other methods), version 4.0b10. Sinauer associates, Sunderland, Massachusetts.

TURNER, S. (1997): Molecular systematics of oxygenic photosynthetic bacteria. - In Origins of Algae and their 
Plastids. - pp. 13-52, Springer, Vienna.

WACKLIN, P.; HofFMANN, L. \& KoMÁREK, J. (2009): Nomenclatural validation of the genetically revised cyanobacterial genus Dolichospermum (Ralfs ex Bornet et Flahault) comb. nova. - Fottea 9: 59-64.

Wayne, L.G.; Brenner, D.J.; Colwell, R.R.; Grimont, P.A.D.; KANDLER, O.; KRICHEVSKY, M.I. \& STARR, M.P. (1987): Report of the ad hoc committee on reconciliation of approaches to bacterial systematics. International Journal of Systematic and Evolutionary Microbiology 37: 463-464.

Whitton, B.A. \& Potts, M. (2000): The ecology of cyanobacteria. Their diversity in time and space. -669 pp., Springer, Berlin.

Wilmotte, A. \& Golubić, S. (1991): Morphological and genetic criteria in the taxonomy of cyanophyta cyanobacteria. Archiv für Hydrobiologie 92: 1-24.

Wilmotte, A. \& Herdman, M. (2001): Phylogenetic relationships among the cyanobacteria based on 16S rRNA sequences. - In: Boone, D.R. \& Castenholz, R.W. (eds): Bergey's manual of systematic bacteriology, $2^{\text {nd }}$ ed.- pp. 487-493., Springer-Verlag, NewYork.

Wilmotte, A.; Turner, S.; Peer, Y. \& Pace, N.R. (1992): Taxonomic study of marine oscillatoriacean strains (cyanobacteria) with narrow trichomes. II. Nucleotide sequence analysis of the $16 \mathrm{~S}$ ribosomal RNA. - Journal of Phycology 28: 828-838.

Zapomělová, E.; Jezberová, J.; Hrouzek, P.; Hisem, D.; Řeháková, K. \& KoмÁrková, J. (2009): Polyphasic characterization of three strains of Anabaena reniformis and Aphanizomenon aphanizomenoides (Cyanobacteria) and their reclassification to Sphaerospermum gen. nov. (incl. Anabaena kisseleviana). - Journal of Phycology 46: 415 .

Zapomělová, E.; Skácelová, O.; Pumann, P.; Kopp, R. \& JANEČEK, E. (2012): Biogeographically interesting planktonic Nostocales (Cyanobacteria) in the Czech Republic and their polyphasic evaluation resulting in taxonomic revisions of Anabaena bergii Ostenfeld 1908 (Chrysosporum gen. nov.) and A. tenericaulis Nygaard 1949 (Dolichospermum tenericaule comb. nova). - Hydrobiologia 698: 353-365.

(C) Czech Phycological Society (2019)

Received August 24, 2018

Accepted November 27, 2018 